\title{
Development of a parametric model for the organization of scientific and technical support during construction.
}

\author{
Mikhail Kashirtsev*, and Dmitry Topchy \\ Moscow State University of Civil Engineering, 129377, Moscow, Russia
}

\begin{abstract}
The aim of the study is to create a parametric model, using which it will be possible to formulate a program of measures carried out during the scientific and technical support of construction (STSC) for each specific object, as well as increase the efficiency of construction production by preventing unaccounted indicators during design. The uniqueness of this model lies in the fact that it adapts to the conditions of any object of high-rise construction. As a result, it will be possible to simulate a set of measures for the implementation of STSC for each unique object. Since the construction of a unique high-rise building requires the use of STSC, the question arises of the application of various methods and methods at each object. The unique high-rise buildings and structures considered within the framework of the STSC are unique, therefore, each needs to apply its own parameters relevant to a particular facility. For example, we can say that any parameter associated with the monitoring of the bases will be different for each object, since the ground conditions for each building under construction are different. To create a model, a number of parameters were selected that are most necessary for inclusion in the STSC regulation for the construction of unique high-rise buildings, and each parameter has its own criterion that varies depending on changes in the characteristics of the construction object. All parameters are either related to actual data on the construction object, such as: air temperature, soil conditions, material of load-bearing structures, etc., or depend on and are regulated by the regulatory documents of the Russian Federation. In this case, one can avoid the subjective opinion that occurs when using the method of expert assessments. Also, avoiding the method of expert assessments can reduce the time spent on the study itself, obtaining a result, and making a forecast.
\end{abstract}

\section{Introduction}

In recent years, in connection with the increasing volume of construction of high-rise buildings, the relevance of such a line of activity as scientific and technical support of construction is growing. [1] In comparison with technical supervision, which has the task of monitoring the activities of contractors, the NTSS has both an applied and a scientific

\footnotetext{
${ }^{*}$ Corresponding author: kashirtsev.mikhaill@mail.ru
} 
approach, namely, it develops and implements new construction methods, as well as modern materials, in order to obtain maximum efficiency and save money and labor costs in the construction and installation work. [2]

Modern construction is characterized by the use of new, more advanced, design solutions, materials, structures and technologies, the development of the specialization of performers and the associated large number of participants in the construction process. [3] In these conditions, along with a competent organization of production and thoughtful coordination of the interaction of performers, effective control over the timely introduction of technical innovations, strict adherence to technological discipline, all quality requirements for the materials and structures used at the facilities becomes crucial. [4]

The very definition of Scientific and technical support sounds like this - (NTSS) - a complex of scientific and analytical, methodological, informational, expert-control and organizational work carried out by specialized organizations in the process of research, design and construction of construction objects to ensure the quality of construction, reliability (safety, functional suitability and durability) of buildings and structures, taking into account the applied non-standard design and technical solutions, materials and structures.[5]

The main problem: the construction of unique high-rise buildings (buildings above 100 meters) is an extremely complex and responsible process, any inaccuracies in the work can lead not only to significant destruction, but also to the collapse of the structure. Based on the above, additional control within the framework of scientific and technical support during construction and installation work is a necessary measure. [6]

Purpose of the study: to develop a system for the formation of organizational and technological measures for the implementation of scientific and technical support for construction. To achieve this goal, the task is to form a list of parameters affecting the improvement of safety and efficiency in the construction of unique high-rise buildings and structures, within the framework of scientific and technical support of construction. [7]

Research Objective:

1. Study of documentation regulating scientific and technical support;

2. Studying the experience of conducting scientific and technical support during the construction of unique high-rise buildings in the city of Moscow;

3. Determination of general parameters for objects of unique construction;

4. Develop a universal parametric model to assess the effectiveness and feasibility of using parameters for unique high-rise buildings and structures within the framework of scientific and technical support for construction;

5. Approbation of the developed parametric model at a unique construction site;

6. Obtaining the results of the study.

The principle of determining parameters and developing an algorithm:

1. Analysis of the implemented NTSS at the objects of unique high-rise construction;

2. Determination of the general parameters of maintaining scientific and technical standards for the objects of unique high-rise construction;

3. Compilation of a list of general parameters and criteria for unique high-rise construction objects;

4. Assignment of weights to criteria based on the analysis of objects and regulatory documents;

5. Development of an algorithm for calculations;

6. Calculation of the effectiveness of the application of organizational and technological measures.

To implement the set task, a parametric model has been developed within the framework of the study, with the use of which it will be possible to form a program of measures carried out with scientific and technical support for the construction of the NTSS 
for each specific object, as well as to increase the efficiency of construction production by preventing unaccounted indicators during design.

The uniqueness of this model lies in the fact that it adapts to the conditions of any highrise building object. As a result, it will be possible to simulate a set of measures for the implementation of NTSS for each unique object.

Since during the construction of a high-rise unique building, it is necessary to apply NTSS, the question arises of the use of various methods and methods at each object. [8]

Unique high-rise buildings and structures considered in the framework of the NTSS are unique, therefore, each one needs to apply its own parameters that are relevant specifically for a particular object. [9]

For example, we can say that any parameter associated with monitoring the foundations will be different for each object, since the soil conditions for each building under construction are different.

To create a model, a number of parameters were selected that are most necessary for inclusion in the regulations on STSS when erecting unique high-rise buildings, and each parameter has its own criterion, which changes depending on changes in the characteristics of the construction object. [10] All parameters are either related to the actual data on the construction object, such as: air temperature, soil conditions, material of supporting structures, etc., or depend and are regulated by the regulatory documents of the Russian Federation. In this case, it is possible to avoid subjective opinion, which takes place when using the method of expert assessments. Also, avoiding the method of expert assessments allows you to reduce the time for the study itself, obtaining a result and making a forecast.

As part of the study, the most important and necessary parameters were identified to ensure full control over the construction of unique high-rise buildings, as well as to increase the efficiency and reduce the project implementation time. These parameters were selected by analyzing scientific and technical support, already implemented projects of unique highrise construction, as well as on the basis of existing regulations governing construction in the Russian Federation. The list of analyzed objects is presented in Appendix A. Based on this analysis, the most vulnerable spots in the construction of unique high-rise objects were identified, leading to a decrease in safety and efficiency. [11]

Each parameter has its own criterion, which is divided into several sampling options depending on the physical, geological and time conditions in which the building is being erected. [12]

The main parameters and criteria of the NTSS are:

1) Geophysical monitoring of soil mass beyond the contour of retaining walls.

When performing work of the zero cycle under difficult soil conditions, it is necessary to monitor the state of soil masses, since when changing or occurring the movement of soil particles, a shift of retaining walls not fixed in time can occur. As a result of the beginning of soil movement, the stability of the retaining wall decreases, it loses its design position and gives a roll. In this case, the collapse of the retaining wall is not excluded, as well as the ingress of groundwater through the formed cracks.

Criterion: category of complexity of engineering and geological conditions, according to SP 22.13330.2016 Foundations of buildings and structures.

2) Hydrological monitoring of soil masses near the pit.

Since the construction of high-rise buildings is associated with the large and weight of building structures, underground water located near the construction site, under the influence of exerted pressure on the ground, can change their characteristics. When monitoring the movement of groundwater, it is possible to track and in time to predict a change in the direction and occurrence of groundwater and take measures. With uncontrolled movement of water, under the influence of pressure from building structures, ground water can flood the pit. 
Criteria: gradation of soil conditions by the nature of anthropogenic impact.

3) Set of concrete strength

The most responsible work in the construction of a high-rise building is the laying of concrete in the foundation structure, since the foundation is the responsible supporting structure of the future building. Concrete is laid non-stop in order to avoid the formation of cold concrete joints and thereby weaken the structure. Since the process of curing with concrete is associated with the hydration reaction, and heat is generated during the hydration of concrete, a large amount of heat will be released when pouring and curing with concrete at large volumes, and as a result, a large temperature gradient with the surface of the structure. This situation will lead to the formation of cracks and chips in the structure.

Criteria: concrete curing period.

4) Diagnostics of the technical condition of machines and mechanisms at the construction site.

To achieve high adaptability in the work on the construction site, a large number of construction equipment are used. The most important are hoisting gears. In the construction of buildings with a height of more than one hundred meters, special and sometimes unique lifting mechanisms are used. To ensure smooth operation, as well as timely preparation for the replacement of equipment used, it is necessary to monitor the technical condition of each machine and mechanism.

Criteria: technical condition of machines and mechanisms for the entire period of operation.

5) The height of the building.

To reduce the time of work while increasing the height of the job, high-tech tooling is used, such as self-moving formwork, protective screens and technological scaffolding. With the increase in the level of the installation horizon to increase the pace of construction, as well as the quality of work, it becomes necessary to provide for the use of the necessary additional equipment.

Criterion: elevation of the installation horizon.

6) Conclusion of an agreement on project support with expertise.

Unique buildings go through a long process of agreeing on all applicable design solutions, since the legislation of the Russian Federation does not regulate the development of unique buildings in detail, in the vast majority of all projects there is a need to develop special technical conditions for a unique high-rise building being built. In this case, the development and passage of expertise is sometimes delayed for a long time. Since during the construction process it may be necessary to amend the design documentation, and this entails a repeated examination, which means an adjustment of the building permit, the construction period may be delayed, and therefore the costs of the project will increase.

7) Systematization of executive documentation

When performing work in accordance with the Urban Planning Code of the Russian Federation, an organization performing construction and installation works must maintain a set of executive documentation and submit for examination to the supervisor assigned to the facility. In the case of unique high-rise buildings, the number of production processes required for survey reaches a significant amount. Systematization of the process of examination and storage of executive documentation will make it possible to reduce the time required for verification of executive documentation by construction control and other bodies responsible for maintaining quality and safety during work.

Criterion: completeness of executive documentation.

8) The introduction of information modeling in the production of work

Currently, when designing unique buildings, there is a process of transition from twodimensional design systems to information design standards. Since the development of unique projects is increasingly carried out using information models, it becomes necessary 
to implement BIM standards directly on the construction site at key stages of the work. These stages include: work below the zero cycle, construction of the aerial parts, special work.

Criterion: the presence of a project developed using an information model.

9) Implementation of access control systems (access control and management system)

The construction of unique high-rise buildings is associated with the daily presence of a huge number of workers and materials at the facility. To control and systematize information on the daily movement of workers, it is necessary to apply a system of control and management of access to the construction site. It is especially important to apply this system at the stage of the highest workload of the construction site, namely when performing work below zero, during the construction of the aboveground part of the building, during special works, as well as during finishing work.

Criterion: period of construction.

\section{Material and Methods}

After compiling a list of key parameters and criteria for them, it is necessary to assign a weight and a value to each criterion, which will vary depending on the construction conditions for each object.

In the parametric model, depending on the degree of expediency and the need to apply one or another parameter, each criterion is assigned its own weight.

Weights have the following gradation:

0.5 - the criterion for this construction project is important and application is necessary to increase efficiency;

0.4 - the criterion for this object is important and the application is advisable to increase efficiency;

0,3 - the criterion for this object is not important, but the application will increase efficiency;

0.2 - the criterion for this object is not important, the use of this parameter will not lead to a significant increase in efficiency;

0,1 - the criterion for this object is not important and its application is not necessary.

Assignment of criteria by the user of the model, taking into account the fact that the values chosen are not subjective, but depend on the physical parameters of the construction object, the construction period and regulatory documentation.

Depending on the selected criteria, the value of the norm of effectiveness of scientific and technical support is formed for each parameter.

Also, the model uses a three-digit gradation tied to the performance of certain parameters.

The system is as follows:

Full implementation of measures for STSC specified in the parameter for the object has a value of - 1 ;

Partial implementation of measures for STSC specified in the parameter for the object has a value of - 0 ;

Failure to perform a single event specified in the parameter for the object has a value of -1 .

The value of the need for execution is assigned automatically for each parameter, depending on the resulting weight of the criterion.

A dependency might look like this:

If the weight value is in the range from 0.1 to 0.2 , the execution value will automatically be applied - 1;

If the weight value is in the range from 0.3 , the execution value 0 will be automatically applied; 
If the weight value is between 0.4 and 0.5 , the execution value of 1 will be automatically applied.

For calculations, I have compiled a formula for finding the percentage of efficiency.

The norm of efficiency is obtained as a result of automatic mathematical calculations that occur in the model as a result of multiplying the weight of the criterion by the value of execution.

As a result, having received the norm of the percentage of effectiveness, you can clearly see which measures will most significantly affect the increase in the percentage of efficiency when applied.

After that, the expert needs to select the actual values of execution, putting down the value of execution: $-1,0,1$.

Having put all the actual values, the actual percentage of efficiency will be calculated when performing the selected activities when performing scientific and technical support.

The actual percentage of efficiency should not be less than the value of the norm of the percentage of efficiency, since otherwise the implementation of the selected measures for scientific and technical support will be inappropriate. [13]

\section{Testing a parametric model at a construction site in the city of Moscow to organize scientific and technical support for the construction process}

To test the developed model at the construction site of a unique high-rise structure, I selected a construction site located at: Moscow, st. Lobachevsky, 120, 119361.

This object is being erected by the builder of Etalon Group of Companies, the name of the object is Wing. The territory of the construction of the projected multi-apartment residential complex with free-standing children's educational institutions and an underground parking lot is located at: Moscow, ZAO, Ramenki district, ul. Lobachevsky, ow. 120.

The site is limited by GSK Geolog in the west, construction sites of the Ogni and Event residential complexes in the north and east, and the Lobachevsky residential complex in the south.

The residential complex consists of three differently tall residential buildings (building No. 1 - western, building No. 2 - northern, building No. 3 - eastern). Within the first floor of residential buildings, commercial premises are located. At the level of the underground floor of the building, they are bordered by an underground attached parking lot, which is structurally separated by expansion joints.

Each residential tower consists of three residential "wings" of individual height. The floors of the "wings" of towers No. 1, No. 2 and No. 3, respectively: 21-26-31, 28-34-40, 25-30-35 floors (excluding the upper technical floor, from "clean floor" to the bottom of the protruding structures no more than $1.8 \mathrm{~m}$ ).

The maximum height of the aboveground part of the complex (excluding the underground floor) is: for the first building $-117,500 \mathrm{~m}$, for the second building $-144,750$ $\mathrm{m}$ and for the third building $-121,550 \mathrm{~m}$.

The designed residential complex belongs to the unique capital construction objects in accordance with clause 2 of Article 48.1 No. 191-Ф3 "Town Planning Code of the Russian Federation".

According to GOST R 27751-2014 p. 10.1, construction projects belonging to the class KS-3 have an increased level of responsibility.

To test the working capacity of the developed model, the model was introduced as part of scientific and technical support for the construction process by the Scientific Research Institute of Design, Technology and Construction Expertise (LLC NII PTES). 
The parametric model developed as part of the final qualification work is registered as: computer programs registration (certificate) number: 2020615013 dated 05/14/2020

The object of study is the high-rise building of the residential complex "Wings", building K2. The project plans to build forty floors and the building will have a height of one hundred thirty-nine meters. At the time of the study, the following work was carried out at the facility: preparatory work, foundation pit construction, foundation construction, all structures below the zero mark were erected. At the moment, the construction is at the stage of erecting an elevated bearing frame of the building at $+25,000$ meters.

Initial data for the parametric model:

Technical report on the results of engineering and geological surveys. Object: "Residential complex, which includes infrastructural objects of socio-cultural purpose at the address: Moscow, st. Lobachevsky, ow. 120. " Volume I and II LLC STF-STROY, Moscow 2017.

Section 6. Project of the organization of construction, subsection 1. Project of the organization of construction of the object: "Residential complex, which includes infrastructural objects of socio-cultural purpose at the address: Moscow, st. Lobachevsky, ow. 120."

For each parameter included in the model, according to the accompanying criteria, a selection was made and weight was assigned to each parameter, based on the obtained initial data.

Automatically, all data and the calculation of the percentage of efficiency were reflected both on the questionnaire questionnaire and on the technical part of the parametric model.

As a result, the normative percentage of efficiency was calculated for the development and application of scientific and technological support for construction. For the object at the time of calculation, a percentage of the efficiency norm was determined equal to $48 \%$. This percentage indicates that for each parameter proposed for the developer or for the organization providing scientific and technical support, a decision must be made on the implementation of routine measures in the amount that gives an efficiency of at least $48 \%$. If the actual efficiency indicator is less than $48 \%$, then the quality of scientific and technical support for the construction will not be achieved and may lead to a decrease in safety, as well as to an increase in costs in case of emergency situations.

The proposed list of parameters was transferred to a group of engineers conducting scientific and technical support at the construction site, namely to employees of the Scientific Research Institute of Design, Technology and Expertise of Construction (LLC NII PTES). After carrying out a mathematical calculation, the parametric model assigned a weight indicator to each parameter, and based on this weight indicator, recommendations were made on the need to carry out certain routine measures suitable for each parameter.

The actual percentage of completion for each parameter may differ from the standard percentage of completion, but in total the total actual percentage of completion should be greater than or equal to the total standard percentage of efficiency.

Based on the presented source data, the results obtained are listed in table 1.

Table 1. The result of the actual execution

\begin{tabular}{|l|l|l|l|l|l|l|l|l|}
\hline \multirow{2}{*}{ № } & \multirow{2}{*}{ Parameter } & \multirow{2}{*}{ criterion } & \multirow{2}{*}{ value } & \multirow{2}{*}{ weight } & \multicolumn{2}{|c|}{ NORM } & \multicolumn{2}{|c|}{ FACT } \\
\cline { 7 - 8 } & & & & norm & Value & fact & Value \\
\hline
\end{tabular}




\begin{tabular}{|c|c|c|c|c|c|c|c|c|}
\hline 1 & $\begin{array}{l}\text { Geophysical } \\
\text { monitoring } \\
\text { of soil mass } \\
\text { beyond the } \\
\text { contour of } \\
\text { retaining } \\
\text { walls. }\end{array}$ & $\begin{array}{l}\text { category of } \\
\text { engineering } \\
\text { and } \\
\text { geological } \\
\text { conditions }\end{array}$ & I (simple) & $30 \%$ & 0 & 0 & 1 & 0.3 \\
\hline 2 & $\begin{array}{l}\text { Hydrological } \\
\text { monitoring } \\
\text { of soil } \\
\text { masses near } \\
\text { the pit. }\end{array}$ & $\begin{array}{l}\text { gradation of } \\
\text { soil } \\
\text { conditions } \\
\text { by the } \\
\text { nature of } \\
\text { anthropogen } \\
\text { ic impact }\end{array}$ & drained & $30 \%$ & 0 & 0 & 1 & 0.3 \\
\hline 3 & $\begin{array}{l}\text { Set of } \\
\text { concrete } \\
\text { strength }\end{array}$ & $\begin{array}{l}\text { concrete } \\
\text { curing } \\
\text { period }\end{array}$ & $\begin{array}{l}\text { from } 1 \text { to } 7 \\
\text { day }\end{array}$ & $30 \%$ & 0 & 0 & 0 & 0 \\
\hline 4 & $\begin{array}{l}\text { Diagnostics } \\
\text { of the } \\
\text { technical } \\
\text { condition of } \\
\text { machines } \\
\text { and } \\
\text { mechanisms } \\
\text { at a } \\
\text { construction } \\
\text { site. }\end{array}$ & $\begin{array}{l}\text { technical } \\
\text { condition of } \\
\text { machines } \\
\text { and } \\
\text { mechanisms } \\
\text { for the } \\
\text { entire period } \\
\text { of operation }\end{array}$ & $\begin{array}{l}\text { up to } 1 \\
\text { year }\end{array}$ & $30 \%$ & 0 & 0 & 1 & 0.3 \\
\hline 5 & $\begin{array}{l}\text { Building } \\
\text { height }\end{array}$ & $\begin{array}{l}\text { Mounting } \\
\text { Horizon } \\
\text { Mark }\end{array}$ & $\begin{array}{l}\text { up to } 30 \\
\text { meters }\end{array}$ & $10 \%$ & -1 & -0.1 & -1 & -0.1 \\
\hline 6 & $\begin{array}{l}\text { The rhythm } \\
\text { of the } \\
\text { delivery of } \\
\text { materials to } \\
\text { the } \\
\text { construction } \\
\text { site }\end{array}$ & $\begin{array}{l}\text { object } \\
\text { location }\end{array}$ & $\begin{array}{l}\text { Up to } 20 \\
\text { kilometers } \\
\text { from the } \\
\text { center }\end{array}$ & $20 \%$ & 0 & 0 & 0 & 0 \\
\hline 7 & $\begin{array}{l}\text { Conclusion } \\
\text { of an } \\
\text { agreement } \\
\text { on project } \\
\text { support with } \\
\text { expertise. }\end{array}$ & $\begin{array}{l}\text { the need to } \\
\text { amend the } \\
\text { design } \\
\text { documentati } \\
\text { on }\end{array}$ & $\begin{array}{l}\text { There is a } \\
\text { need }\end{array}$ & $50 \%$ & 1 & 0.5 & 1 & 0.5 \\
\hline 8 & $\begin{array}{l}\text { Application } \\
\text { of various } \\
\text { mounting } \\
\text { technologies } \\
\text { (mounting } \\
\text { from wheels) }\end{array}$ & $\begin{array}{l}\text { Built-up } \\
\text { area }\end{array}$ & $\begin{array}{l}\text { More than } \\
10 \%\end{array}$ & $10 \%$ & -1 & -0.1 & -1 & -0.1 \\
\hline 9 & $\begin{array}{l}\text { Systematizat } \\
\text { ion of } \\
\text { executive } \\
\text { documentati } \\
\text { on }\end{array}$ & $\begin{array}{l}\text { completenes } \\
\mathrm{s}\end{array}$ & full set & $50 \%$ & 1 & 0.5 & 1 & 0.5 \\
\hline
\end{tabular}




\begin{tabular}{|c|c|c|c|c|c|c|c|c|}
\hline 10 & $\begin{array}{l}\text { Implementati } \\
\text { on of } \\
\text { information } \\
\text { modeling in } \\
\text { work }\end{array}$ & $\begin{array}{l}\text { the presence } \\
\text { of a project } \\
\text { developed } \\
\text { using the } \\
\text { information } \\
\text { model }\end{array}$ & $\begin{array}{l}\text { BIM model } \\
\text { not } \\
\text { developed }\end{array}$ & $10 \%$ & -1 & -0.1 & 0 & 0 \\
\hline 11 & $\begin{array}{l}\text { ACS system } \\
\text { device for } \\
\text { monitoring } \\
\text { material and } \\
\text { labor } \\
\text { resources }\end{array}$ & $\begin{array}{l}\text { construction } \\
\text { period }\end{array}$ & $\begin{array}{l}\text { The } \\
\text { constructio } \\
\text { n of the } \\
\text { aerial part }\end{array}$ & $50 \%$ & 1 & 0.5 & 0 & 0 \\
\hline 12 & $\begin{array}{l}\text { Monitoring } \\
\text { the timing of } \\
\text { work and } \\
\text { making a } \\
\text { construction } \\
\text { forecast. }\end{array}$ & $\begin{array}{l}\text { construction } \\
\text { period }\end{array}$ & $\begin{array}{l}\text { The } \\
\text { constructio } \\
\text { n of the } \\
\text { aerial part }\end{array}$ & $50 \%$ & 1 & 0.5 & 1 & 0.5 \\
\hline 13 & $\begin{array}{l}\text { Monitoring } \\
\text { the impact of } \\
\text { construction } \\
\text { on nearby } \\
\text { existing } \\
\text { buildings }\end{array}$ & $\begin{array}{l}\text { The distance } \\
\text { from the } \\
\text { foundation } \\
\text { pit to the } \\
\text { surrounding } \\
\text { buildings }\end{array}$ & $\begin{array}{l}\text { More than } \\
5 \mathrm{~m}\end{array}$ & $10 \%$ & -1 & -0.1 & -1 & -0.1 \\
\hline 14 & $\begin{array}{l}\text { Organization } \\
\text { of regulatory } \\
\text { measures to } \\
\text { prevent } \\
\text { seismic } \\
\text { impact on } \\
\text { the building } \\
\text { under } \\
\text { construction }\end{array}$ & $\begin{array}{l}\text { seismic } \\
\text { resistance } \\
\text { category (4 } \\
\text { cat.) }\end{array}$ & $\begin{array}{c}\text { III } \\
\text { category }\end{array}$ & $50 \%$ & 1 & 0.4 & 0 & 0 \\
\hline \multicolumn{4}{|c|}{ Total } & & \multicolumn{2}{|c|}{$\frac{2}{48}$} & & $\begin{array}{l}2.1 \\
50\end{array}$ \\
\hline
\end{tabular}

\section{Results}

As a result of the calculation, on the basis of the sampling, an actual percentage of efficiency equal to fifty was obtained. The obtained actual percentage of efficiency is greater than the indicator of the norm of efficiency, and therefore, we can conclude that the activities that will be carried out as part of the scientific and technical support during the construction process will be effective and appropriate.

The result of the work was the developed parametric model for assessing the effectiveness of the application of the system of scientific and technical support for the construction of unique high-rise buildings. This model is registered as a computer program (Registration number (certificate) 2020615013).

\section{References}


1. MRDS 02-08 Manual on scientific and technical support and monitoring of buildings and structures under construction, including large-span, high-rise and unique ones. OJSC "KTB ZHB”, State Unitary Enterprise "NIIMosstroy", Federal State Unitary Enterprise "Research Center Building", State Unitary Enterprise MNIITEP, GOSSTROYNADZOR Moscow, 2008, 76 p.

2. GOST 31937-2011 Buildings and structures. Rules for inspection and monitoring of technical condition. The State Unitary Enterprise of Moscow "Moscow Research and Design Institute of Typology, Experimental Design" (GUP "MNIITEP") with the participation of the State Unitary Enterprise of Moscow "Research Institute of Moscow Construction" (GUP "NIIMosstroy"), Russia, 2014, 54 p.

3. GOST 32019-2012 Monitoring the technical condition of unique buildings and structures. Rules for the design and installation of stationary monitoring systems (stations). The State Unitary Enterprise of the City of Moscow, Moscow Research and Design Institute of Typology, Experimental Design (GUP MNIITEP), Russia, 2014, 24 p.

4. TR 182-08 Technical recommendations for scientific and technical support and monitoring of the construction of large-span, high-rise and other unique buildings and structures. State Unitary Enterprise of the City of Moscow, Research Institute of Moscow Construction (GUP "NIIMosstroy"), Russia, 2008, 27 p.

5. V.V. Granev, Scientific and technical support for the design of buildings and structures (LLC Publishing House PGS, Moscow 2018)

6. M.S. Kashirtsev, D.V. Topchiy, Theoretical aspects of the implementation of scientific and technical support at the construction stage during the construction of high-rise of buildings (Publishing house St. Petersburg State University of Architecture and Civil Engineering, St. Petersburg, 2019)

7. D.V. Topchiy, A.Yu. Yurgaitis, M.N. Danilochkin, Technology and organization of construction production: International Center for the Development and Implementation of Self-Regulation Mechanisms (Publishing House, Moscow, 2018)

8. M.S. Kashirtsev, D.V. Topchy, Implementation of scientific and technical support for the construction of high-rise buildings, days of student science (Publishing House National Research Moscow State University of Civil Engineering, Moscow, 2019)

9. D.V. Topchiy, A.Yu. Yurgaitis, M.N. Danilochkin, Scientific and technical support of construction and design as an additional element of the qualimetric model for ensuring the quality of finished building products, Journal: "Technology and Organization of Building Production", Publisher: International Center for the Development and Implementation of Self-regulatory Mechanisms, Moscow, (2018)

10. A.A. Lapidus, Scientific and technical support for research, design and construction as an indispensable element in achieving the required project indicators, Vestnik MGSU National Research Moscow State University of Civil Engineering, Moscow, (2019)

11. D.V. Topchiy, A.Yu. Yurgaitis, M.-B.H. Kodzoev, I.M. Khaliullin, Strain-strain monitoring of the stress-strain state of structures of the underground part of buildings and structures with scientific and technical support for construction and re-profiling objects, Building Materials, Advertising and Publishing Firm Stroymaterialy, Moscow, (2019

12. D.V. Topchy, V.S. Chernigov, Carrying out tensometric monitoring of the technical and stress-strain state of the underground part of buildings and structures as part of scientific and technical support for the construction of unique objects, Ensuring the 
quality of construction in Moscow based on modern achievements of science and technology, SAMPolygraphist LLC, Moscow, (2019) 